\title{
NILAI KEARIFAN UNGKAPAN BUDAYA JAWA "RUKUN AGAWE SANTOSA" DALAM GAGASAN PEMIKIRAN EMMANUEL LEVINAS
}

\author{
Theresia Pratiwiningsih \\ Sekolah Tinggi Filsafat Teologi Widya Sasana Malang \\ threspij@gmail.com
}

\begin{abstract}
The focus of this research is theme of Javanese local wisdom culture which related to Javanese proverb expressions about "Rukun Agawe Santosa". My aim is to explore further how these Javanese proverbs are carried out by the Javanese people themselves in daily life. To deepen this study the methodology that I used was Comparative Study with an awareness of the ethical values and harmony that was sparked in the Javanese proverb expression "Rukun Agawe Santosa". Through Emannuel Levinas's thoughts on Ethics and in the expression of Javanese local wisdom culture, I find that the value of environmental ethics is growing today due to the emergence of a stronger awareness of the importance of maintaining relationships with "the other" ie the earth and all its contents but in general ethics are the most talked about in the context of human relations and ultimately the Javanese cultural expression "Rukun Agawe Santosa" becomes the main capital and the most appropriate way of creating solid unity and unity so as to create a strong and peaceful society.
\end{abstract}

Keywords: Pillars, Peace, Ethics, Relations, The others.

\section{PENDAHULUAN}

Sejak dibangku SD dahulu, bahkan sejak di Taman Kanak-Kanak peribahasa "Rukun Agawe Santosa" sudah diperkenalkan. Semoga sekarang pun masih demikian, diperkenalkan dan bahkan ditekankan kepada anak-anak kita di seluruh negeri ini. Dengan contoh yang sederhana dan populer. Manusia selalu ada bersama dengan sesamanya. Armada dalam buku Relasionalitas, mengatakan bahwa "Aku" manusia memiliki kebenaran kodrati bahwa dia hidup, menjadi bagian dari komunitasnya. Tidak ada manusia yang kita maknai dirinya "sendirian", dalam maksud tidak memiliki komunitas (Armada, 2018). Pemikirannya tersebut sesungguhnya hendak mengaskan bahwa manusia selalu bergumul dan menjadi bersama dengan komunitas. Manusia tidak memiliki makna jika ia berdiri seorang sendiri tetapi manusia akan memiliki makna jika ia ada bersama dengan orang lain yang disatukan dalam komunitas.

Mungkin masih ingat dimana-mana sama ketika bapak-ibu guru memberi contoh sapu lidi, jika disatukan akan kuat bisa digunakan untuk menyapu, jika terlepas "suh-nya" - tali pengikat, akan tercerai berai tak bermanfaat. Walau terkesan kuno dan basi, namun sesungguhnya tetap relevan untuk selalu diingat dan diwujud nyatakan dalam kehidupan masyarakat yang bhineka ini. Bahkan, seorang kepala negara merasa perlu untuk mengingatkan kembali pentingnya persatuan dan kesatuan, dengan lantang menentang segala bentuk yang menyebabkan perselisihan dan pertentangan di negeri tercinta ini

Menjunjung tinggi Empat Pilar Kebangsaan, Pancasila, UUD 1945, NKRI, dan Bhineka Tunggal Ika menjadi harga mati yang harus dipertahankan. Kita bisa mendukung persatuan dan kesatuan dalam 


\section{7 | JURNAL IHMU BUDAY}

Volume 8, Nomor 2, 2020

kelompok-kelompok kecil di sekitar kita, tanpa harus meninggalkan jati diri pribadi kita masing-masing dan sebuah ungkapan tradisi budaya Jawa "Rukun Agawe Sentosa" ini dapat menjadi modal dasar dan utama dalam usaha mewujudkannya.

\section{METODE}

Untuk mendalami studi ini Metodologi yang penulis gunakan ialah Studi Komparatif. Penelitian studi komparatif yang dimaksud merupakan penelitian yang bersifat membandingkan. Studi komparatif memiliki tujuan untuk membandingkan bukan hanya persamaan tetapi juga perbedaan dari dua atau lebih fakta dan sifat objek yang akan diteliti berdasarkan suatu kerangka berpikir tertentu (Creswell, 2018, Kuswarini, et al., 2020). Dalam Studi komparatif ini variabelnya hanya satu namun digunakan untuk sampel yang lebih dari satu atau dalam kurun waktu yang berbeda. Jadi, penelitian studi komparatif adalah sebuah penelitian yang dapat digunakan untuk membandingkan antara minimal dua kelompok dari suatu variabel tertentu.

\section{HASIL DAN PEMBAHASAN}

\section{Peribahasa "Rukun Agawe Santosa"}

Ungkapan peribahasa Rukun
Agawe Santosa sering digabungkan
dengan ungkapan Crah Agawe Bubrah
sehingga menjadi Rukun Agawe Santosa,
Crah Agawe Bubrah. Arti dari ungkapan
tersebut adalah "Rukun membuat kuat
sentosa, bertengkar membuat rusak".
Ungkapan ini dapat dikatakan sebagai
sebuah nasihat supaya kita berusaha
menciptakan kedamaian dan kerukunan
dalam hidup keluarga, bermasyarakat dan
bernegara (Pardi, 2013). Budaya Jawa
sangat menekankan kerukunan, bahkan,
kerukunan sebagai ciri dan kekhasan orang
Jawa. Kerelaan untuk mengalah atau

melepaskan kepentingan pribadi, kelompok, atau golongan agar tetap terjaga kerukunan hidup bersama dan bermasyarakat. Dengan demikian semua orang diharapkan rela mengorbankan kepentingan pribadinya demi terciptanya kerukunan dan kedamaian. Dalam kehidupan masyarakat Jawa, seseorang yang tidak berjiwa damai dan mampu menjaga kerukunan disebut sebagai wong ora lumrah (manusia aneh)

Ungkapan Rukun Agawe Santosa (rukun membuat sentosa) berlawanan dengan crah agawe bubrah (berselisih membuat rusak). Di sini menjadi jelas bahwa kerukunan dapat memudahkan penyelesaian setiap urusan dan dapat memberi kelegaan bagi semua pihak. Tugas-tugas berat akan menjadi ringan karena dikerjakan dan diselesaikan bersama-sama dalam sukacita dan kerukunan Untuk mencapai tujuan bersama yang diharapkan seperti keamanan lingkungan, pembuatan fasilitas umum, mencapai kemerdekaan, mengusir penjajah, melumpuhkan penjahat yang mengganggu lingkungan bersama dan lainlain perlu melibatkan semua warga dengan dilandasi oleh semangat hidup rukun. Persoalan bersama harus dipikul bersamasama. Dengan mengusahakan kerukunan akan menciptakan persatuan dan kesatuan yang kokoh kuat demi terwujudnya masyarakat yang adil, makmur dan sentosa. Budaya yang telah menjiwai hidup masyarakat Jawa adalah wujud semangat gotong royong yang masih sangat kuat dan kental. Hingga sekarang dapat terlihat bahwa semangat gotong royong masih sangat kuat dan kental dalam kehidupan masyarakat desa, baik dalam pelaksanaan pembangunan fisik ataupun pembangunan mental. Oleh sebab itu dalam kehidupan masyarakat desa dikenal adanya kerja bakti yang disebut gugur gunung sebagai ekspresi semangat kebersamaan warga. 


\section{8 | JURNAL IHMU BUDAY}

Volume 8, Nomor 2, 2020

Ungkapan crah agawe bubrah (berselisih membuat rusak) tidak dapat disangkal. Perselisihan pasti menimbulkan keretakan hubungan atau mengganggu persatuan, baik dalam lingkup RT, RW, kampung, desa, ataupun negara. Oleh sebab itu semua orang perlu menyadari bahwa perbedaan memang tidak dapat dihindarkan dalam kehidupan bersama. Akan tetapi yang terpenting adalah mengelola perbedaan itu agar tidak menimbulkan keretakan dan mengganggu kerukunan. Sejarah telah membuktikan kepada kita, bangsa Indonesia. Secara logika tidaklah mungkin bangsa Belanda yang kecil dan jaraknya sangat jauh dari Indonesia dapat menguasai dan menjajah bangsa kita yang besar dan sangat luas. Akan tetapi, karena ketika itu bangsa Indonesia tidak bersatu, tidak rukun, akibatnya dengan leluasa bangsa Belanda dapat menjajah Indonesia dalam waktu yang sangat lama. Namun dalam perjalanan sejarah, nasib yang menimpa bangsa kita sebagai bangsa terjajah yang menderita telah menumbuhkan semangat kesatuan yang sangat amat kokoh. Bangsa Indonesia telah bertekad hidup bersatu padu menjalin hidup rukun demi mampu mengusir penjajah dari bumi pertiwi Indonesia. Akhirnya, dengan semangat perstuan dan kerukunan yang selalu menggelora di dada setiap anak bangsa, Indonesia berhasil hidup merdeka setelah melakukan perjuangan bersama yang sangat panjang dan melelahkan. Jadi rukun merupakan senjata yang sangat ampuh dalam mencapai tujuan yang menyangkut kepentingan bersama. Tidak ada pekerjaan berat jika kita melaksanakan secara bersama-sama dalam semangat rukun. Sebaliknya, perselisihan justru akan merusak persatuan dan kebersamaan. Oleh sebab itu, kita harus sadar bahwa perselisihan dan percekcokan dapat memberikan peluang bagi pihak-pihak yang tidak bertanggungjawab dan akan
E-ISSN: 2621-5101 P-ISSN:2354-7294

memanfaatkan kelemahan itu demi tujuan pribadi.

Ungkapan rukun agawe santosa dan crah agawe bubrah merupakan pusat dari salah satu sikap hidup Jawa sehingga orang yang tidak mengindahkan nilai-nilai kerukunan disebut wong nyeleneh atau orang aneh dan biasanya akan disisihkan atau "dikucilkan" dari kehidupan bersama dalam masyarakat. Wujud dari semangat hidup rukun sebagai sumber ungkapan gotong royong, gugur gunung, dan saiyeg saeka kapti (seia sekata dalam satu tujuan) untuk kepentingan bersama-sama dan sebagainya.

\section{Gagasan Emmanuel Levinas}

Emmanuel Levinas terlahir tanggal 12 Januari 1906 di Kovno,Lithuania, sebagai anak tertua dari tiga bersaudara. Dengan bahasa Rusia sebagai bahasa ibu, Levinas mengenal karya-karya penulis Rusia terkenal, seperti Lermontov, Gogol. Turgenev, Tolstoy, Dostoevsky, dan Pushkin. Buku-buku inilah yang akhirnya membawa Levinas kepada filsafat karena membahas "hal-hal yang fundamental... mudah dibaca sebagai pencarian terhadap makna hidup (Jill, 2001). Akan tetapi, Rusia bukanlah satu-satunya kultur yang mempengaruhi Levinas secara mendalam.

Dengan pecahnya Perang Dunia ke II pada tahun 1939, Levinas mengikuti wajib militer Prancis dan mendapat tugas sebagai penerjemah bahasa Rusia dan Jerman. Setahun kemudian dia ditangkap tentara Jerman, dijadikan tawanan perang di Rennes. Pengalaman menjadi tahanan perang sangat mewarnai karya-karyanya khususnya Existence and Existents: refleksi fenomenologis atas kegiatankegiatan yang paling sederhana, seperti makan dan tidur, pergulatan dengan rasa kehilangan dan kebebasan, perasaan mengenai waktu, rasa pasif yang mutlak dan ketidakberdayaan. Masalah intersubyektivitas atau relasi dengan orang lain pun menjadi salah satu tema pokok filsafat Levinas (Thomas, 2012). 


\section{9 | JURNAL IHMU BUDAY}

Volume 8, Nomor 2, 2020

Fenomenologi menunjukkan bahwa akal budi kita tidak terperangkap dalam diri sendiri, melainkan milik publik dan saling berkorelasi dengan dunia. Jika kita mendengar kata "etika" biasanya dengan mudah kita menghubungkan dengan aturan moral atau prinsip hidup baik. Teori etika pada umumnya mengajarkan orang tentang apa yang harus dan apa yang tidak boleh dilakukan dalam kaitan dengan harkat dan martabat pribadi manusia. Munculnya kesadaran yang lebih kuat terhadap pentingnya mempertahankan dan memelihara relasi yang baik dengan yang lain, yang bukan hanya seorang manusia tetapi juga alam sekitar mengakibatkan etika lingkungan sosial berkembang pesat dewasa ini. Yang paling banyak dibahas dalam relasi kontekstual antar pribadi manusia ialah etika lingkungan. Bagi Levinas etika selalu dikaitkan dengan kontak atau perjumpaan real dengan pribadi lain, bukan hanya sekedar dalam pemikiran yang abstrak mengenai hubungan antarmanusia. Maka etika dapat diartikan sebagai sebuah kondisi atau ruang dimana kita dapat merasa tergerak dan dituntut untuk memberikan respon atas kehadiran orang lain bersama kita.

Levinas menegaskan bahwa etika pertama-tama bukan sebuah teori tentang tata cara hidup baik sebagai pribadi manusia atau hal menyangkut peraturan yang harus ditaati, tetapi etika merupakan sebuah perjumpaan langsung dengan orang lain. Seluruh teori tentang etika dan aturan moral yang ada seharusnya dibangun atas dasar perjumpaan ini. Perjumpaan dengan orang lain ini menuntut kita untuk memberikan respon dan kitapun tidak bisa tinggal diam begitu saja. Mengingat etika pada hakikatnya tentang hubungan antara kita sebagai subjek dan orang lain, maka sangat penting bagi kita untuk dapat memahami bagaimana Levinas menggambarkan karakter pribadi manusia dari sudut fenomenologi. Pemahaman ini
E-ISSN: 2621-5101 P-ISSN:2354-7294

mempermudah kita untuk mengerti konsep etika levinas secara umum sebagai sebuah keterbukaan terhadap yang lain. Secara positif, etika atau "yang-etis" berarti adanya sikap terbuka dan rasa hormat dan menghargai perbedaan. Subjek tidak mudah terperosok ke dalam diri dan pemikirannya sendiri, melainkan mengarahkan diri dan pandangannya ke luar, yaitu ke arah Yang-Lain dengan segala perbedaannya. Inilah makna asali transendensi, yakni gerakan keluar dari diri sendiri dalam keterbukaan dan rasa hormat serta menghargai terhadap apa saja yang ditemui dalam perjalanan hidupnya.

Relasi etis dengan orang lain diungkapkan lewat sikap dan perbuatan yang tidak otoriter, tetapi justru membiarkannya dalam segala perbedaan dan keunikannya. Hal ini sangat penting khususnya dalam relasi kita dengan YangLain yang adalah manusia lain. Sangatlah tidak penting kita memberi cap kepada orang lain atau memasukkannya ke dalam kategori pemikiran yang sudah dimiliki sejak awal, karena tindakan seperti itu sesungguhnya merupakan upaya kita menguasai mereka atau menjadikan mereka sebagai bagian dari milik kita.

Aku adalah obyek sebuah kesadaran dan bukan subjeknya. Dalam "Yang Etis" sang subjek mau terbuka terhadap manusia lain; yang menjadi prioritas bukan lagi sang Aku, melainkan Yang Lain. Tanggungjawab terhadap hidup orang lain hanya dapat dilakukan jika tidak ada sikap dominan dari sang $\mathrm{Aku}$, melainkan hanya ada rasa hormat dan penghargaan terhadap segala perbedaannya yang ada. Seberapa etis relasi terbentuk dengan baik dapat ditentukan dari sejauh apa subjek menghargai dan menerima keunikan dan perbedaan orang lain serta bersedia dipertanyakan olehnya.

Karena Gagasan atau ideologi tertentu, kita tidak lagi dapat berjabat tangan dengan orang lain atau duduk 
berdampingan sebagai saudara dan saudari sesama manusia. Kebersamaan sebagai manusia seringkali menjadi terancam dan bahkan hilang karena kita berpegang erat pada gagasan kita mengenai identitas diri kita maupun identitas orang lain. Persaudaraan yang sesungguhnya bersifat alamiah berubah menjadi sesuatu yang diharapkan terjadi dan diimpi-impikan. Menurut Levinas relasi yang sejati, baru dapat terjadi melalui kontak atau pertemuan konkret dengan orang lain khususnya pada wajah, karena wajah merupakan "signifikasi tanpa konteks" dan "bermakna pada dirinya sendiri", hal ini merupakan makna kehadiran seorang manusia yang tidak ditentukan oleh konteks dimana ia dikenali dan temukan. Entah kaya atau miskin, memiliki status sosial rendah atau tinggi, berasal dari suku atau agama mayoritas atau minoritas, memiliki pandangan politik liberal atau konservatif, itu semua tidak menjadi penentu, manusia tetaplah berarti dan bermakna sebagai pribadi..

Menjadi hal penting bagi Levinas, bahwa gerakan sang Aku untuk keluar dari diri sendiri (transendensi) tidak hanya berarti melewati melainkan juga menaiki. artinya, transendensi selalu menyangkut gerakan keluar (outward) dan naik (upward) ke arah ketinggian (the Height) atau sesuatu yang lebih superior. Dengan demikian gaerakan metafisik, sebagai sebuah transendensi selalu merupakan transasendensi (transascendence). Dalam relasi seperti ini yang memungkinkan adanya tanggapan dalam bentuk ucapan, "silahkan", anda (berjalan) lebih dulu" saat kita membukakan pintu bagi orang lain. Dalam relasi ini orang lain selalu mendapat perhatian dan prioritas pertama, bukan diri kita. Hak-hak yang harus dipertahankan pertama-tama adalah hak orang lain, bukan hak diri kita. Itulah sebabnya mengapa humanisme yang ditawarkan oleh Levinas kerap kali disebut sebagai "humanisme (bagi) Yang-Lain" dan bukan "humanisme (bagi) sang Aku"(Nidra, 2006).

\section{Comparation/Pembandingan}

Manusia sebagai mahluk yang selalu bertemu dan berinterkasi dengan sesamanya. Manusia tidak dapat berjuang sendiri. Hakikat manusia sebagai mahluk sosial adalah kesadaran manusia terhadap status dan posisinya dalam kehidupan bersama serta bagaimana tanggungjawab dan kewajibannya dalam hidup bersama. Istilah sosial mempunyai arti kemasyarakatan. Dalam arti sempit kepentingan bersama atau masyarakat menjadi yang terdahulu. Manusia sebagai mahluk sosial adalah mahluk yang hidup bermasyarakat karena pada dasarnya setiap hidup individu tidak terlepas dari manusia yang lain.(Nursid, 1986)

Interaksi yang terjadi antar manusia mengandaikan suatu relasi yang baik yang menciptakan suatu kedekatan yang mendalam. Karena sejatinya kehidupan manusia merupakan perpaduan antara manusia dengan manusia yang lain. Oleh karenanya hidup bersama dengan sesama harus ditandai dengan sikap saling berbagi satu sama lain. Hal itu dijelaskan lebih jelas oleh Armada dalam uraian berikut ini:

\footnotetext{
"Relasi "Aku dan sesamaku." Relasi

"Aku dan sesamaku (engkau)" memiliki kebenaran bahwa keduanya berada dalam zona komunikasi sehari-hari hidup manusia. Aku menjadi eksistensi yang mengelola dan menjaga keberadaanku, keberlangsunganku, dan keindahanku. Demikian juga dengan sesamaku. Keduanya adalah manusiamanusia menjadi. Keduanya adalah sosok-sosok yang ambil bagian satu sma lain dalam hidup bersama. Saat aku dan sesamaku berkomunikasi, saat itu tercipta "kami" (we). Kami bukan perpaduan antara aku dan sesamaku, melainkan "keberadaan bersama". Dan, kebersamaan itu menyusun komunitas. Natura
} 


\section{1 | JURNAL IHMU BUDAYA}

Volume 8, Nomor 2, 2020

komunitas dengan kata lain adalah komunikatif. Dalam komunikasi tidak ada yang disisihkan.”(Armada, 2018)

\section{Ungkapan peribahasa Rukun}

Agawe Santosa berarti rukun membuat kuat sentosa. Ungkapan Jawa ini adalah sebuah nasihat agar kita berusaha menciptakan situasi rukun dalam kehidupan keluarga dan bermasyarakat serta bernegara. Bagi orang Jawa kerukunan merupakan satunya perasaan antar manusia dalam menjalankan visi bersama dengan membuang berbagai pertengkaran dan pertentangan. Dalam Bahasa Jawa rukun iku angedohi padu don yang artinya rukun itu menjauhkan pertengkaran. Rukun menjadi syarat utama untuk membangun situasi masyarakat yang harmonis. Ada sebuah ungkapan Jawa yang berkaitan dengan terminologi rukun, yakni crah agawe bubrah rukun gawe santosa yang berarti pertikaian membuat perceraian, rukun membangun kekuatan. Seperti yang dijelaskan pada bagian pembahasan ungkapan di atas.

Konsep tentang manusia sebagai "ada" belum sungguh menjelaskan kodrat relasional. Manusia berelasi artinya manusia memberi ruang supaya manusia lain dapat pula memenuhi dirinya. Dengan demikian kehadiran orang lain menjadi berarti. Kehadiran orang lain melengkapi kekurangan.(Mohammad, 2015)

Dalam pandangan budaya orang Jawa, orang hidup itu harus memiliki etika dan tolong menolong. Ajaran ini berasal dari pandangan bahwa orang tidak dapat hidup sendiri, kodrat manusia membutuhkan kehadiran orang lain dan disana dibutuhkan usaha untuk selalu hidup rukun satu dengan yang lain. Kodrat manusia sebagai manusia sosial membedakan manusia dengan ciptaan Tuhan yang lain. Pandangan ini sejalan dengan pemikiran yang disampaikan
E-ISSN: 2621-5101 P-ISSN:2354-7294

Levinas, bahwa etika selalu berhubungan dengan pertemuan langsung dengan orang lain, bukan dengan pemikiran yang bersifat abstrak mengenai relasi antar manusia. Etika adalah sebuah situasi atau ruang dimana kita merasa tergerak dan dituntut untuk memberikan respon pada kehadiran orang lain bersama kita. Orang menjadi yang utama dalam usaha membangun hidup rukun bersama dengan yang lain.

Dalam struktur kehidupan di Jawa, masyarakat suatu desa nyaris terikat dalam semangat persaudaraan yang tinggi. Karena persaudaraan yang sangat tinggi itulah setiap anggota masyarakat selalu menjaga kenyamanan dan kerukunan bersama. Banyak kegiatan dalam masyarakat yang membangun semangat persaudaraan dan menjaga kenyamanan serta kerukunan dalam masyarakat.(Iman, 2012) Semua kegiatan-kegiatan yang dibuat dan dilaksanakan semata-mata agar dapat menyatukan semua masyarakat dan menumbuhkan kerukunan dan sikap serta rasa saling mengasihi satu sama lain. Di sini kedekatan semakin terjalin satu dengan yang lain.

Ada ungkapan seorang imam yang mengatakan demikian dalam homili saat Perayaan Ekaristi yang bagi saya menjadi real dalam mengusahakan kerukunan, ungkapannya sebagai berikut.

Orang yang ingin menciptakan hidup
"Rukun" bersama orang lain, maka ia
juga harus berusaha bersikap
"Reken" terhadap orang lain, Rukun -
Reken"( Kotbah Denni, 2018).

Ungkapan ini saya rasa benar juga jika kita ingin bisa hidup rukun satu dengan yang lain maka dalam diri kita harus berusaha mengembangkan sikap "Reken" terhadap orang lain yang berarti kita menganggap kehadiran orang lain yang ada disekitar kita sebagai diri pribadi. Rukun tidak akan terjadi jika satu sama lain tidak menghargai kehadiran orang lain. Hal ini menjadi trend pada masa 


\section{2 | JURNAL IHMU BUDAY}

Volume 8, Nomor 2, 2020 sekarang. Dengan kemajuan teknologi masing-masing orang sibuk dengan dirinya sendiri, orang lebih memilih sendiri dan justru berelasi dengan orang yang berjarak jauh dengannya ketimbang dengan orang yang ada dihadapannya atau disekitarnya. Orang yang ada didekatnya tidak di "Reken" sedangkan mereka sibuk dengan dunianya sendiri. Jika ini yang terjadi terus menerus maka banyak hal yang menyulitkan di dalam membangun budaya Rukun.

Ungkapan Rukun Agawe Santosa yang diartikan rukun membuat sentosa berlawanan dengan crah agawe bubrah yakni berselisih membuat rusak. Itu juga yang terjadi jika dalam hidup kebersamaan kurang dapat mengusahakan nilai-nilai baik dalam hidup bersama. Kecenderungan manusia biasanya lebih menunjukkan egois diri dan saling menjatuhkan dengan berselisih, manusia mudah berpikir negatif terhadap sesamanya dan selalu ingin dipenuhi apa yang menjadi haknya. Jika ini yang terjadi terus menerus maka hidup Rukun Agawe Santosa tidak akan terjadi dalam hidup kebersamaan.

Dalam pandangan Levinas juga membahas tentang hal relasi ini, dalam kebersamaan dengan orang lain hendaknya orang lain selalu mendapat perhatian dan prioritas pertama, bukan diri kita. Hak-hak yang harus dipertahankan pertama-tama adalah hak orang lain, bukan hak diri sendiri. Maka itulah sebabnya humanisme yang ditawarkan Levinas disebut sebagai "humanisme (bagi) Yang-Lain" dan bukan "humanisme (bagi) sang Aku". Kita diharapkan untuk selalu berpikir untuk kebaikan orang lain. Berselisih dengan orang lain hanya demi hak dan kepentingan diri sendiri dapat menimbulkan rusaknya relasi antar pribadi dan bahkan di zaman sekarang ini orang semakin berani untuk memilih berselisih demi kepentingan dirinya.Hidup bersama orang lain pasti akan menemukan banyak perbedaan
Relasi antara I and Thou (Tuhan) hanya terjadi mungkin apabila terjadi relasi antara I and Thou (sesame manusia), religiusitas hanya menjadi mungkin bila manusia memiliki relasi perdamaian dengan sesamanya. Relasi ini bertumpu pada kesadaran yang mendalam tentang "Aku" manusia. Jika seseorang menyadari bahwa dirinya memiliki "Aku" dan sesamanya juga memiliki kesadaran yang sama, "aku"-dirinya, maka relasi keduanya sebenarnya merupakan sebuah bentuk penyatuan dua "Aku". Tidak terjadi pertentangan, melainkan pengandaiannya: sedang terjadi pemenuhan yang terpadu, yang sempurna. Sedang terjadi keutuhan "Aku" (Armada, 2018). Hal ini menguatkan ungkapan budaya Jawa ini, dimana "Rukun Agawe Sentosa" mengandaikan kesadaran yang baik dalam membangun relasi dengan sesamanya. Relasi timbak balik yang baik dari kedua pribadi sangat diperlukan demi terwujudnya kondisi yang damai sentosa. Dan sebaliknya jika salah satu idak dapat mewujudkan dan menyatukan keutuhan "Aku" maka yang terjadi adalah Crah Agawe Bubrah dimana yang ada hanya perselisihan.

\section{SIMPULAN}

Bangsa Indonesia adalah bangsa yang hidup dalam keberagaman baik dalam agama, budaya, sosial dan ekonomi. Sesungguhnya begitu kaya bangsa ini jika masing-masing pribadi mampu mengolah keberagaman ini dalam satu kata yakni "Rukun". Bangsa ini dapat membangun negara menjadi lebih baik sepanjang waktu hanya dalam kerukunan dan kedamaian.

Penghayatan orang Jawa akan kebersamaan dalam kerukunan sesungguhnya sangat tinggi. Hal ini dapat dilihat dengan berbagai kegiatan atau aktivitas yang terjadi khususnya di daerahdaerah pedesaan, terlihat terasa kental sekali bagaimana kebesamaan mereka. 


\section{3 | JURNAL IHMU BUDAY}

Volume 8, Nomor 2, 2020
Rukun Agawe Sentosa adalah ungkapan budaya yang selalu ditanamkan dalam diri setiap pribadi orang Jawa. Tidak jarang orang Jawa dengan kehalusan sikap dan budinya menunjukkan jati diri sebagai orang Jawa yang memiliki Etika yang terlihat lebih halus dari budaya lain. Sikap selalu ingin mengalah dari yang lain demi memgusahakan perdamaian seringkali kita temui dengan berbagai ungkapaanungkapan kecil yang terucap seperti : "Narima Ing Pandum" atau menerima jatah secara ikhlas, "Wani ngalah Luhur Wekasane" atau berani mengalah luhur pada akhirnya dan masih banyak lagi ungkapan lainnya.

Dari ungkapan "Rukun Agawe Sentosa" dapat ditemukan banyak nilainilai keutamaan yang terkandung di dalamnya, nilai-nilai keutamaan itu adalah Nilai Etika Penghargaan dan Nilai etika keterbukaan terhadap keberadaan dan keberagaman orang lain. Nilai yang pertama, Nilai Etika Penghargaan. Dasar pemikiran dari nilai Etika penghargaan ini adalah gagasan pemikiran Emmanuel Levinas. Inti dari pemikiran Levinas tentang teori etika ini ialah mengajarkan apa yang harus dan tidak harus dilakukan dalam kaitannya dengan harkat dan martabat manusia. Etika ini muncul akibat dari kesadaran yang kuat akan pentingnya memelihara hubungan yang baik dengan "yang lain" yang bukan hanya manusia tetapi dengan alam sekitar. Bagi Levinas etika selalu terkait realitas bertemunya pribadi, bukan sekedar pemikiran yang bersifat abstrak mengenai relasi antarmanusia. Etika menjadi sebuah situasi atau ruang dimana kita terusik dan dituntut untuk memberikan tanggapan atau respon penghargaan yang pada kehadiran orang lain. Etika membantu manusia dalam berelasi dengan baik dengan orang lain. Dalam ungkapan budaya Jawa "Rukun Agawe Sentosa”, mengajak orang untuk sungguh dapat mengungkapkan kerukunan lewat menghargai martabat manusia sebagaimana mestinya, agar keadaan damai dan sentosa dapat terwujud ditengah hidup masyarakat. Orang yang cenderung mengabaikan etika penghargaan terhadap orang lain akan banyak mengalami kesulitan dalam berelasi khususnya dalam usaha membangun kerukunan. Orang itu akan cenderung dijauhi oleh yang lain dan pada akhirnya akan mengalami kesendirian atau keterasingan dalam hidupnya

Nilai yang kedua, Nilai Etika Keterbukaan. Titik tolak nilai Etika Keterbukaan ini di dasari pemikiran Levinas bahwa etika pada hakikatnya menyangkut relasi antara diri kita sebagai subjek dan orang lain, gambaran karakter diri manusia (the self) dari sudut fenomenologi mempermudah kita memahami konsep etika levinas secara umum sebagai sebuah keterbukaan terhadap yang lain. Perselisihan pasti menimbulkan keretakan hubungan atau mengganggu persatuan, baik dalam lingkup RT, RW, kampung, desa, ataupun negara. Oleh sebab itu diharapkan semua orang perlu menyadari bahwa perbedaan memang tidak dapat dihindarkan dalam kehidupan bersama dengan yang lain. Yang terpenting adalah bagaimana mengelola perbedaan itu agar tidak menimbulkan kehancuran dan mengganggu kerukunan. Orang harus mau terbuka dan menerima keberagaman yang realitanya memang tidak dapat dihindarkan di negara Indonesia yang hidup dalam keberagaman ini. Terbuka terhadap kesamaan dirasa mudah, namun justru lewat ungkapan Budaya Jawa "Rukun Agawe Sentosa" kita mau berjuang untuk dapat menerima dan terbuka terhadap perbedaan sebagaimana gagasan Levinas di atas.

Wujud dari semangat hidup rukun sebagai inti dari ungkapan "Rukun Agawe Sentosa" dan upaya untuk mewujudkan dua nilai etika baik etika penghargaan dan etika keterbukaan ialah gotong royong, gugur gunung, dan saiyeg saeka kapti (seia 
sekata dalam satu tujuan) untuk kepentingan bersama-sama dan demi kondisi damai dan sentosa yang diharapharapkan, dengan kata lain diperlukan pembaharuan terus menerus dari setiap pribadi khususnya meningkatkan integritas pribadi manusia itu sendiri.

\section{Daftar Pustaka}

A.Denny Firmanto, Homili Ekaristi, dalam penutupan sidang Kapitel Provinsi PIJ Indonesia, 12 November 2108.

Armada Riyanto. 2018. Relasionalitas, filsafat fondasi interpretasi: aku, teks, Liyan, Fenomen, Yogyakarta: Kanisius.

Burhanuddin Salam. 1997. Etika Sosial, Asas Moral dalam kehidupan Sosial, Jakarta: PT Rineka Cipta,

Cahier de L'Herne. 1991. Levina,. "Secularisation et Faim", Chicago: L'Herne, 1991.

Erfi Firmansyah, Refleksi budaya Jawa dalam novel bumi manusia dan anak semua bangsa persfektif filsafat, https://jurnal.unej.ac.id/index.php/LIT /article/view/6124

Faturochman. 2018. Psikologi Relasi Sosial, Yogyakarta: Pustaka Pelajar.

Iman Budi Santosa. 2012. Spiritualitas Jawa Sejarah, Laku dan Intisari Ajaran, Yogyakarta: Memayu Publishing.

Jill Robbins. 2001. Levinas, Interview with Francois Poirie, is it Righteous to Be?: Interviews with Emmanuel Levinas, Stanford: Stanford University Press.

John W. Creswell. 2018. Research Design: Pendekatan metode Kualitatif, Kuantitatif dan Campuran, Yogyakarta: Pustaka Pelajar.

Kuswarini, P., Hasyim, M., Chotimah, Irma N.H. 2020. Othering The Self as a Form of Mimicry in The English Translation of Hirata's
Laskar Pelangi. Journa of Critical Reviews. 7 (19), 1286-1295

Mohammad A Syuropati. 2015. Kumpulan Mutiara Kearifan Jawa, Yogyakarta: Syura Media Utama.

Nidra Poller. 2016. Levinas, Humanism of the Other, Urbana dan Chicago: University of Illinois Press.

Nursid Sumaatmadja. 1986. Pengantar studi Sosial, Bandung: Alumni.

Pardi Suratno, Henniy Astiyanto/ 2013. Gusti Ora Sare, Yogyakarta: Adiwacana.

Shintya Putri Setiowati. 2020. Pembentukan Karakter Anak Pada Lagu Tokecang, Jawa Barat. Jurnal Ilmu Budaya. 8 (1), 172-177

Thomas Hidya T. 2012. Enigma Wajah Orang Lain: menggali Pemikiran Emmanuel Levinas, Hidup dan Karir Levinas, Jakarta: Gramedia. 